\title{
Empirical Spirits: Islam, Spiritism, and the Virtues of Science in Iran
}

\author{
ALIREZA DOOSTDAR
}

\author{
University of Chicago
}

IN T R O D U C T I O N

Iranians today largely take the legitimacy and prestige of the modern empirical sciences for granted. This prestige is a historical achievement, the effect of decades, if not centuries, of human effort. Its history is not one of linear intellectual progress, a cumulative triumph of reason over superstition or truth over error. Instead, it is a story of convergences and divergences among many different kinds of practice over a long stretch of time and in the face of myriad forms of resistance and contestation. These practices have included small-scale acts of discourse - translation and instruction, oral and textual disputation, learned exchange and popular entertainment — but also large-scale biopolitical projects involving hygiene, eugenics, psychiatry, pedagogy, and so on. They have been implicated in the rise of new classes of professionals such as scientists, engineers, technicians, bureaucrats, and educators, and in the building of new institutions and the undermining of old ones. No less important is that these practices have been deeply entangled with the state's powers of legislation, disciplining, and coercion. ${ }^{1}$

Just as the history of the rise of modern science cannot be reduced to a tale of unilinear progress, so the actors involved should not be caricatured as secular progressive modernists battling reactionary traditionists. For one thing, commitment to Islamic tradition has translated to a spectrum of attitudes toward

\footnotetext{
Acknowledgments: I am grateful to Hussein Ali Agrama, Asad Ahmed, Dan Arnold, Naor Ben-Yehoyada, Steve Caton, Sarah Hammerschlag, Smita Lahiri, Bruce Lincoln, Elham Mireshghi, Margaret Mitchell, Afsaneh Najmabadi, Noah Salomon, Daniel Stolz, and the anonymous CSSH reviewers for comments on earlier versions of this article. All translations from Persian are my own.

${ }^{1}$ For the rise of modern science in the first half of the twentieth century, see Schayegh 2009. For educational reform in the Qajar and Pahlavi periods, see Ringer 2001; and Koyagi 2009. Arjomand (1997) discusses some aspects of the early reception of modern astronomy. Najmabadi (2014) offers insights into the rise and influence of modern biomedicine, psychology, psychiatry, and psychosexology, including their impact on Shi'i legal epistemology. Lotfalian (2004) examines critiques of technoscience after the Islamic Revolution.
} 
modern science, including enthusiastic adoption and appropriation. ${ }^{2}$ Scholars have noted the myriad ways in which Muslim activists and intellectuals in Iran and elsewhere have drawn on modern scientific knowledge and notions of rationality and progress in order to accomplish a variety of objectives: countering charges of reaction and superstition, attacking materialist, secularist, and heterodox religious doctrines, and criticizing the conditions of Muslim communities with the aim of advancing alternative agendas for reform. ${ }^{3}$

While many "traditionists" over the past century have embraced modern science, many of the Iranian proponents of science typically imagined as "secularists" have been committed to explicitly religious projects. Scholarship about the latter group is scant, and usually limited to a handful of intellectuals whose religious commitments are by and large described as solitary and eccentric. ${ }^{4}$ My first aim in this article is to challenge this narrow view by drawing attention to the influence of Spiritism and psychical research among Iranian intellectuals in the first half of the twentieth century. Spiritism enabled these intellectuals, as it did many of their fellow travelers in Europe and elsewhere, to ground their religious cosmologies in what they took to be universal modern science and to tether their moral teachings to what they defended as objective empirical research. If their aspirations now seem quixotic and their practices bizarre, their claims once circulated in respectable modernist circles and were taken seriously by intellectual, religious, and political elites.

A study of Spiritism's reception also allows us to notice some shared features across various modes of religious scientism, Islamic and otherwise. Chief among these for my purposes is the adoption of certain scientific virtues as fundamental for moral leadership and reform. I will argue that we need to look for the influence of modern science not only in its reshaping of the landscape of knowledge, but also in its power to mold the moral subjectivities of reformers through selective absorption into long-continuous traditions of virtue. ${ }^{5}$

Together, these arguments suggest that while modern science was received as novel and in many ways discontinuous from received forms of knowledge and practice in Iran, it was also assimilated into existing traditions of moral reform, and in that sense should be understood as contributing to the extension of certain well-established practices from the past into the future. These practices of virtue have in turn served to consolidate science's power and prestige.

2 The assumption that new forms of knowledge and technology were always introduced by modernizers needs to be reexamined. On this issue, see Daniel Stolz's discussion of precision mechanical time-keeping among the 'ulama in eighteenth- and nineteenth-century Egypt (2015).

3 See Chehabi 1990; Deeb 2006; Fuchs 2014; Elshakry 2009; Rudnyckyj 2010; and Stolz 2012.

4 Two of the better-known figures are Ahmad Kasravi and Hoseyn Kazemzadeh Iranshahr. On Kasravi, who is usually described as a "deist," see Ridgeon 2006; and Vahdat 2002: 85-90. On Iranshahr, a theosophist, see Boroujerdi 2006; and Vahdat 2002: 83-85.

5 My understanding of tradition and virtue is derived chiefly from MacIntyre 2012; and Asad 1986; 1993; 2015. 
MORAL REFORM, SCIENCE, AND VIRTUE

Nineteenth- and twentieth-century Iranian modernists called for sweeping political and moral reforms, and even political demands were often couched in moral terms. ${ }^{6}$ A unifying feature of modernist moral discourse prior to the 1905-1911 Constitutional Revolution and for some decades afterward was to identify the political, economic, and military weaknesses of Iran with the moral deficiency of the Qajar monarchy (1794-1921/26), and sometimes with Islam and Arabs. This corruption was articulated as part of a larger package of ills, which also included the superstition and torpor of the masses, apathy and lack of manly zeal among the elites, and reactionary, ignorant, and deceitful leadership among the 'ulama. Modernists offered a variety of prescriptions for overcoming these ills, including the adoption of modern scientific knowledge. $^{7}$

Modernist attempts at reform have been primarily understood in terms of a break with the recent past and an aspiration toward a future imagined on the model of European progress (itself sometimes imagined in terms of a glorious ancient Iranian past). This has led to a scholarly neglect of certain important continuities, including the enduring relevance of the Perso-Islamic tradition of moral refinement and virtuous conduct. ${ }^{8}$ Mana Kia has shown that modernists up to and through the Constitutionalist period drew on a Persian tradition of moral cultivation and refinement of character in shaping their reformist discourse. ${ }^{9}$ Even the acquisition of knowledge, including modern science, was articulated in terms of virtue: "In the context of older Persianate ideas, knowledge had long been the cornerstone of moral perfection, and was linked to ideas about the virtuous conduct of individuals and communities. This was because learning was thought to bestow the discernment necessary for the practice of moderation, the highest virtue." ${ }^{\prime 10}$ Studies of the reception of the modern sciences in Iran have neglected its connection to the development of the virtues. Hence Cyrus Schayegh, in his excellent study of the rise of the sciences between 1900 and 1950, amply documents how modern psychology and pedagogy were deployed for moral reform - especially for the development of "willpower" necessary for producing "self-reliant personalities"-but he makes no attempt to connect these projects of moral reform to the older tradition of the virtues. ${ }^{11}$

${ }^{6}$ Kia 2015a.

${ }^{7}$ On modernists' diagnoses of the ills that plagued Iran and their prescriptions for reform, see Kashani-Sabet 2000; Kia 2015a; and Schayegh 2009.

${ }^{8}$ See Kia 2015a.

9 Ibid.

${ }^{10}$ Ibid.: 148.

11 Schayegh 2009: 157-93. He does come close to recognizing the relevance of the virtues, for example in his discussion of "the moralistic assumptions inherent in supposedly objective scientific statements" (ibid.: 91). 
The Perso-Islamic tradition of moral refinement was centrally concerned with self-cultivation. ${ }^{12}$ If moral reformers saw themselves as participants in this tradition, they must also have considered it necessary to cultivate certain virtues in themselves (or to appear to have done so) as proper to their role as reformers. Such specialized virtues were elaborated for a wide range of practices in the Islamic tradition. For example, Mehmet Kadri Karabela has discussed post-classical theories about the virtues proper to the practice of argumentation, including thoughtfulness, fairness, avoiding wheeling-dealing, and abstaining from pretension. ${ }^{13}$ Muftis, those scholars called on by their followers to provide fatwas, have long had their own dedicated literary genre-known as $a d a b$ al-mufti - for defining their qualifications and virtues. These have included self-reliance, generosity, pleasant manners, a quick wit, and professional competence in Arabic. ${ }^{14}$

One of my arguments in this article is that modern science provided the imaginative resources with which some moral reformers could define their own qualifications on the model of professional scientists - that is, in terms of the virtues proper to scientific practice. Historians of science have long recognized the centrality of certain virtues and their attendant sensibilities and modes of comportment for disciplined scientific activity. These scholars have shown how practitioners of science are trained to develop distinctive modes of feeling, perceiving, and understanding, particular forms of embodied relationship to their objects of inquiry through observation, experiment, and manipulation, and specific norms of relating to their peers and others whom they view as their audience. ${ }^{15}$ These affect-charged constellations of understanding, perceiving, and behaving are at the very heart of science, determining for example what it means to quantify, maintain objectivity, and conduct empirical research. $^{16}$

Scientific virtues may be elaborated out of sensibilities prevalent in a broader social milieu. For example, Steven Shapin has shown that in seventeenth-century England, scientists negotiated the problem of the credibility of observations, experiments, and testimony by recourse to the codes of gentlemanly honor, trust, and civility. ${ }^{17}$ More recently, Matthew Stanley has argued that the astronomer A. S. Eddington drew on a Quaker concept of

${ }^{12} \mathrm{Kia} 2015$ b. See also the anthropological literature on ethical discipline in Islam, especially Asad 1986; 1993; Agrama 2010; Hirschkind 2006; and Mahmood 2005.

13 Karabela 2010: 167.

14 Masud 2015. Also see Agrama 2010 for an anthropological account of the practice of ethical self-care between mufti and fatwa-seeker in Egypt.

15 Daston 1995; Daston and Galison 1992; Schaeffer 1994; Shapin 1994; Shapin and Schaeffer 1989.

16 Daston 1995.

17 Shapin 1994. 
"seeking" to develop an approach to scientific exploration on the basis of "physical intuition and observation." 18

The borrowing of virtues also occurs in the opposite direction. While to my knowledge there have been no systematic explorations of the ways in which the virtues thought to constitute scientific practice have been adopted in religious contexts, we do have a rich literature on how certain religious movements have modeled their epistemologies on those of empirical science. ${ }^{19}$ Scholars have also described religious practitioners who imagine their own work in terms of testing, experience, and experimentation. ${ }^{20} \mathrm{My}$ work builds on the insights of this research, but places more explicit emphasis on the normative valences attached to the virtues of professional scientific activity as something to be emulated by religious leaders and moral reformers.

\section{EXPERIMENTAL SPIRIT SCIENCE}

In the early decades of the twentieth century, Spiritism succeeded in attracting interest from among Iranian elites seeking to reconcile their commitments to modern science with their religious longings and dedication to moral reform. The most active of these elites were francophone intellectuals devoted to education and scientific popularization. Their visions were global in scope. Europe set their intellectual compass, even when they were deeply critical of the increasingly calamitous events there. And although they focused their activities primarily in Iran, they saw themselves as participants in an international ecumene committed to achieving global peace and unity through moral reform. In their universalist visions, their commitments to science and education, their reliance on global networks of elite sociality, and their harnessing of the new infrastructures of steam, print, post, and telegraph, the Iranian Spiritists joined Freemasons, Baha'is, reformist Sufis, Theosophists, and other innovators, while also establishing a new grammar and practice of scientized spirituality that would endure beyond their own immediate horizons. ${ }^{21}$

Spiritism's arrival in Iran can largely be credited to one man. Mirza Khalil Khan Saqafi (1863-1944) was a physician, educator, bureaucrat, diplomat, essayist, and translator. He studied modern medicine at the Dar al-Funun polytechnic college before securing a series of government assignments. Around 1895, he won the blessings of the Qajar monarch Naser al-Din Shah to travel

18 Stanley 2007: 11.

19 For example, Hammer 2001; and Monroe 2008. Cecire takes up the question of "epistemic virtues" in literary experimentalism (2015).

20 For example, Klassen 2011.

21 See Bayat 2009 on Iranian Freemasonry; Warburg, Hvithamar, and Warmind 2005 on Baha'i globalism; and van den Bos 2002 on modern Sufi reformulations. For the broader context of global Masonic, Occultist, and Spiritist/Spiritualist circulation, see Bogdan and Djurdjevic 2013; Green 2015; van der Veer 2001; and Zarcone 2013. For the influence of Spiritism beyond Europe, see Hess 1991 on Brazil; Palmié 2002 on Cuba; and Hoskins 2015 on Vietnam. 
to Paris for further medical training. Four years later, he returned to Tehran and joined the physicians in the employ of the Qajar court. He became a personal physician and close confidant to the new monarch Mozaffar al-Din Shah and received the title of A'lam al-Dowleh (the most learned of the state).

During the second half of his life, Khalil Khan augmented his medical practice with public intellectual engagements and state administrative positions, including a three-year stint as Tehran's first post-revolution mayor. He translated textbooks on medicine, agriculture, and industry, a book on space and time, Jules Lermina's 1881 novel Le Fils de Monte-Cristo, and selections of Persian classical literature that he co-translated and published as Le Jardin des Délices. He also compiled a Persian-French dictionary, authored original works on chemistry, moral refinement, and literature, and penned essays on culture, politics, and society.

Khalil Khan considered his greatest accomplishment to have been the introduction and propagation of ma'refat al-ruh-e tajrobati or "experimental spirit science." 22 By this he principally meant Spiritism-the movement founded in France by Allan Kardec in 1857 that was devoted to communication with the spirits of the dead through turning tables, planchettes, and human mediums. ${ }^{23}$ Like Kardec, Khalil Khan considered Spiritism a scientific doctrine. At the time, ma 'refat al-ruh - the science of spirits/soul/psyche-was a concept that could refer to a range of knowledges and practices that in Europe had gradually clustered into Spiritism, psychical research, and experimental psychology. The boundaries between these were still hotly contested at the turn of the century, when Khalil Khan was in Paris for medical training. The eventual victory of experimental psychology and the waning of the other two were only decided later. ${ }^{24}$ In Iran, too, experimental psychology was established as an academic discipline only after 1925 when Ali Akbar Siasi coined the neologism ravan-shenasi to translate psychologie and replace the older 'elm al-nafs, which had primarily been understood to refer to the scholastic philosophical psychology based on introspection. ${ }^{25}$ Siasi used the Persian word ravan for psyche and equated that with both the Arabic nafs and ruh. ${ }^{26}$ But all three terms - ravan, ruh, and nafs - were interchangeable in scientific discourse beyond the $1920 \mathrm{~s}$ and to some extent even today. Khalil Khan-the-Spiritist's ma 'refat al-ruh and Siasi-the-psychologist's ravan-shenasi were easily exchangeable terms, even if their authors used them toward clearly differentiated and even opposing ends.

22 Saqafi 1943: 207.

23 Monroe 2008; Sharp 2006.

24 See Brower 2010.

25 My account of the development of psychology in Iran and Siasi's influence is indebted to Najmabadi 2014; and Schayegh 2009. In France, too, the early experimental psychologists struggled to distance their newborn field from introspective philosophical psychology. See Brower 2010.

26 On the concepts of ruh and nafs in Islam, see Calverley 2012. 
To understand Khalil Khan's fascination with Spiritism and his efforts to propagate the science in Iran, we need to return to his years of graduate medical training in Paris. It was there that he says he met Dr. Jules Bernard Luys (18281897), a renowned neurologist who had made important contributions to the understanding of human brain anatomy and neurological diseases. ${ }^{27}$ Luys had long been fascinated with hysteria and hypnosis, conducting experiments on the effects of medication at a distance, storing cerebral activities in magnetic crowns, and visualizing brain and body emanations. ${ }^{28}$ Many of Luys' experiments were performed in public, either at the Hôpital de la Charite or at his own residence, and they attracted crowds of Parisians curious to see his strange demonstrations firsthand.

By the time Khalil Khan arrived in Paris in the mid-1890s, Luys was near the end of his life in the public spotlight. He died in 1897, but his brief acquaintance must have been enough to launch Khalil Khan into the world of Spiritism and psychical research. It was probably at La Charité or Luys' residence that he was introduced to the vibrant Parisian Spiritist scene. In time, he would translate and popularize many works of Spiritism and psychical research, including those by Allan Kardec, Camille Flammarion, Charles Richet, and Gabriel Delanne. He was joined in his efforts by a coterie of fellow travelers, all from among the Iranian bureaucratic and military elite. They included Ali-Reza Bahrami Mohazzeb al-Saltaneh, an ophthalmologist and Khalil Khan's colleague at the mayor's office, Reza-Qoli Rafi“ al-Molk, a one-time employee of the antiques office in the Ministry of Education, Dust-Mohammad Khan E'tesam al-Dowleh, a grandson of Naser al-Din Shah and colonel in the army, and Mahmud Vahid Sa'd (Vahid al-Dowleh), a member of the fifth parliament, director of an educational society promoting adult literacy, and son of Javad Sa'd al-Dowleh (himself a famous politician and briefly prime minister).

In the mid-1920s Khalil Khan founded the Society of Experimental Spirit Science (anjoman-e ma'refat al-ruh-e tajrobati) in Tehran as a venue for regular communication with spirits. The society met weekly, first at the personal residence of Colonel Mohammad-Baqer Khan Nakhjavan, and later at the house of Colonel Mohammad Khan Razmara. ${ }^{29}$ Both men had served in the powerful Cossack Brigade and were the fathers of prominent military men who also took part in the Spirit Society's meetings. ${ }^{30}$ Within a year or two,

27 On Luys, see Parent 2002; Parent and Parent 2011; and Monroe 2008: 238-39, 249. Khalil Khan was already familiar with neurology from his years at the Dar al-Funun. In fact, he helped translate a chapter on neurological diseases from Augustin Grisolle's Traité élémentaire et pratique de pathologie interne (Schayegh 2009: 244n16).

28 Parent and Parent 2011: 133-34.

29 Modarresi Chahardehi 2008: 60; Saqafi E‘zaz 1972: 105.

30 Saqafi E‘zaz 1972: 101. Mohammad Nakhjavan Amir Movassaq, the son of MohammadBaqer Khan, served as Army chief of staff, war minister, senator, and governor of Khuzestan between 1927 and 1952. Haji Ali Razmara, the son of Mohammad Khan Razmara, served as 
the meetings were moved to the house of Vahid al-Dowleh, who would eventually succeed Khalil Khan as director of the society. According to Khalil Khan's son, all of the "eminent and enlightened members" of the society believed in telepathy and clairvoyance, which "have been scientifically proven." However, there were at first a few "newcomers" who had not yet grasped experimental spirit science and instead retained their "superstitious beliefs" in "coffee divination, sleight of hand, palmistry, and the like." 31

The staple event each week was a séance. If a suitable medium —often a young, frail woman - was available, she would be hypnotized by Khalil Khan in order to enter a trance state and communicate with the spirits of deceased individuals awaiting reincarnation. ${ }^{32}$ Once contact was established, the medium would write down the spirits' messages or speak them out loud. In the absence of mediums, members would sit around a wooden table and communicate with the spirit world telegraphically using a wooden cigar box that glided on a sheet inscribed with the letters of the Persian and French alphabets. $^{33}$

The Society of Experimental Spirit Science hosted séances with some of the most renowned souls in history. They included statesmen (Mirza Taqi Khan Amir Kabir, Karim Khan Zand, Yazid ibn Mu'awiya, Józef Piłsudski), scientists (Avicenna, Camille Flammarion), and poets (Hafez, Sa'di, Khayyam). The souls reported on their circumstances in the "fourth dimension," on the good and evil deeds they had committed during their many lifetimes, and on the workings of the cosmos and reincarnation. The loftier the souls, the richer their insights. For example, Mirza Taqi Khan Amir Kabir (18071852), Naser al-Din Shah's famous prime minister and the founder of Khalil Khan's alma mater the Dar al-Funun, told the Spirit Society that he was on the "first level" of the spirit world. His first earthly life had been as a "jungle savage" but he had gradually ascended the ranks such that by his five thousandth return when he lived as Amir Kabir he was so elevated that he did not require any additional returns to earth. The reason, as he explained it, was that: "On earth, I did nothing but good. I always tried to do good for people. I was never selfish, and I never wanted anyone to be harmed. I never desired to do anything out of ostentation. And this is why I am very comfortable." ${ }^{, 34}$ Other souls were not as fortunate. Yazid ibn Mu'awiya, the Umayyad

\footnotetext{
Army chief of staff several times between 1943 and 1948. He was appointed prime minister in June 1950 but was assassinated only nine months later.

31 Ibid.: 102 .

32 I have been unable to uncover much about the participation of women in the early Iranian Spiritist movement. Later, Khalil Khan's own granddaughter Parvin-Dokht Saqafi E‘zaz became a medium.

33 Hadi 1972; Mazhari 1977; Saqafi E‘zaz 1972.

34 Saqafi 1929: 288-309.
} 
caliph who ordered the murder of Prophet Muhammad's grandson Imam Husayn, confessed that he had been wicked in all two thousand and fifty-nine of his lives, most recently as a depraved menial worker in Africa. 'Omar Khayyam pled guilty to having been a "materialist" who had composed much nonsense in his poetry. Hafez lamented that he had wasted his life away in debauchery and drinking. And Avicenna had been a selfish opportunist who had read all he could of the Khwarazmshahi library before torching the building to prevent others from benefitting from the knowledge within. ${ }^{35}$

These revelations were not mere fodder for casual conversation and amusement. They provided firsthand testimonies with which Spiritists could debate and evaluate the various legacies they had inherited from Iranian, Islamic, and European history. As a mode of critical historical inquiry their séances were very much of a piece with broader modernist concerns. But for the Spiritists, this historical inquiry was explicitly positioned within a framework of moral reflection and self-scrutiny. Khalil Khan wrote that experimental spirit science was in the first instance "an instrument for moral exercise [varzesh-e akhlaqi] for traversing the stages of spiritual progress." He argued that nothing was more effective in awakening people, prodding them to reflect on their actions, and encouraging them to improve themselves, than listening to the confessions of those spirits who had committed ugly deeds on earth and learning about their current condition. ${ }^{36}$

Spiritists considered their method of communication with disembodied souls to be the fruit of modern scientific discovery. They believed that their séances would lead to "a revolution in both science and religion; that they would bring about a dawn of spiritual science and a faith supported by concrete evidence." ${ }^{37}$ Like the movement's founder Allan Kardec, Khalil Khan viewed Spiritism in positivist terms. ${ }^{38}$ Playing on the two meanings of the word 'elm as both science and knowledge, he wrote: "Science/knowledge ['elm] means knowing realities [haqayeq], which means knowing things that are true and are not false or uncertain [mashkuk]. For example, the science of constructing automobiles means knowing realities or true things that, should one act according to them, an automobile will be made and will run and reach a determined destination. The same goes for the science of chemistry, the science of physics, the science of arithmetic, the science of geography, experimental spirit science, and other positive sciences."39 According to Khalil Khan and other Spiritists, the moral principles garnered from conversations with the souls of the dead

35 Ibid.: 303-9.

36 Saqafi and Bahrami 1936: 52-53.

37 Lachapelle 2011: 5. On the uneasy relationship between French Spiritists and the custodians of normal science, on one hand, and Catholic orthodoxy, on the other, see Brower 2010; Monroe 2008; Lachapelle 2011; and Sharp 2006.

38 Monroe 2008: 110.

39 Saqafi 1943: 252-53. 
amounted to positive knowledge as good as any other scientific fact. These moral facts were counterpoised to a cacophony of conflicting moral systems based not on reason but on blind faith:

Up till now the foundations of morality have been laid upon various blindly followed beliefs ['aqayed-e gunagun-e ta'abbodi] and these beliefs are different in each nation and are at odds with one another. On the other hand, scientific beliefs which have led to the progress of natural civilization are the same in the whole world and there is no variation among them.... There is only one truth and there is no difference in that which is real. An internal [moral] police which would pertain to all nations would be founded upon scientific beliefs; that is, it should be based on the new discoveries of experimental spirit science. ${ }^{40}$

Just as the sciences of nature were everywhere the same, Khalil Khan argued, so should be the sciences of morality. The former had given rise to an advanced "natural civilization," but until moral truths were established through the discoveries of experimental spirit science, this civilization would be morally backward. The outward policing of morality needed to be bolstered by an inner police or conscience fully convinced of the truth of positive moral facts as discovered by Spiritism.

According to Khalil Khan and his associates, Spiritism taught the virtues of forgiveness, sacrifice, charity, patience, duty, respect for the Golden Rule, controlling one's lowly passions and desires, equity, avoidance of idleness and sloth, education, and putting one's knowledge to practice. ${ }^{41}$ Some of these virtues were characteristic of a broader modernist orientation - these included discipline and avoidance of laziness, pursuing knowledge, and fulfilling one's duties. ${ }^{42}$ Others were clearly adopted from Kardec's teachings. The Golden Rule, as Monroe has pointed out, was the basis for Spiritism's "fundamentally social conception of morality" in which the locus of good and evil was found in one's conduct in relation to others. Spiritists therefore placed a high premium on charity and denigrated selfishness. ${ }^{43}$ But these virtues were also fully consonant with the Persian tradition of moral refinement, in which, as Kia has noted, moral substance was manifest in proper conduct in relation to others. $^{44}$

Despite his contention that, prior to the emergence of Spiritism, moralities were everywhere based on blind and conflicting faiths, Khalil Khan's own biography shows a more complicated picture. What changed in his approach to the virtues when he converted to Spiritism was not that he abandoned his prior commitments wholesale, but that he jettisoned only certain aspects, namely those requiring absolute respect for the commands received through

40 Saqafi 1935: 55.

41 Saqafi 1907; Vahid Sa‘d 1929.

42 See Schayegh 2009.

43 Monroe 2008: 106.

44 Kia 2015 b. 
authoritative Islamic texts. In 1891-1892, only a few years before departing for France, Khalil Khan authored a treatise on moral refinement for children and youth. He began the text in the name of God, then proceeded to offer moral advice in fifty-odd pages on every aspect of daily conduct. "The best virtue and the highest moral refinement," he began, was to follow "the command of God and the prophet, to obey whatever the great men of religion [bozorgan-e din] have ordered." ${ }^{45} \mathrm{He}$ further argued that every action should be based on reasoned contemplation: when reason judges compassion to be good, for example, we should act accordingly. ${ }^{46}$

Both of these positions were received from the moral tradition that Khalil Khan inhabited as a Qajar aristocrat. Spiritism would lead him to abandon all references to prophets, imams, and "great men of religion." He even stopped opening his texts in the name of God. But he would preserve his inherited commitment to reason. All the virtues he had espoused seem to have remained unscathed as well, with the exception of fealty to Islamic authority. Only now he bolstered them with empirical verification. Finally, his works hewed close to the Persian tradition of virtue in his use of short didactic aphorisms, his deployment of the format of hekayat (stories or anecdotes meant to impart moral lessons), and his reliance on the vocabulary of nasihat (moral advice). ${ }^{47}$

This continuity notwithstanding, the role of moral scientist required additional capacities and dispositions, and these Khalil Khan adapted from his understanding of the virtues of professional scientific practice. As a positive science, he considered Spiritism to share certain features with physics and chemistry in terms of the attitudes it demanded from seekers of knowledge. First, empirical science required a freedom of thought unbridled by the arbitrary dictates of blindly followed religion. If anything, Khalil Khan argued that only empirical scientific knowledge should set limits on freedom of thought (azadi-ye khial). ${ }^{48}$ Sometimes he went as far as to define free-thinking in terms of receptivity to scientific truth. For example, he wrote that there were two kinds of people, those who followed reason and humanity ('aql va ensaniat) and those who obeyed false beliefs and delusions ('aqayed-e bateleh va mowhumat). The first group made progress along with the advances of science, but the second were unable to attain truths unless their false beliefs were wiped out and they were made free-thinkers. ${ }^{49}$

Second, empirical scientific research required ascetic discipline, strong will, and patient struggle. Quoting Voltaire - one of his heroes-Khalil Khan

45 Saqafi 1891-1892: 1 .

46 Ibid.: $1-2$.

47 On the use of hekayat in Persian moral advice literature, see Kia 2014. On Iranian modernist translations of morally edifying European literature, including La Fontaine's fables (of which Khalil Khan was particularly fond), see Karimi-Hakkak 1995.

48 Saqafi 1943: 229.

49 Ibid.: 232. 
wrote that science or knowledge of the truth was a reward achieved only through hard work. It would not just fall to a person "from the sky" as if by divine grace. Sloth and lack of discipline would deprive one of the reward of knowledge. ${ }^{50}$ In the context of the séance, disciplined effort took concrete form in the calibration of the experiment, the management of participants' conduct, and the guidance of communication with the spirits.

According to Khalil Khan, the séance leader needed to carefully select the participants at the beginning of a session to ensure success, since the spiritual states of the members and their "fluidic reserves" could promote or hinder the manifestation of spirit phenomena. The correct choice of participants would be verified either by a guardian spirit (ruh-e hami) or through practice, and the séance leader would make modifications as necessary. Positive results could sometimes take months or even years to achieve, so participants needed to be serious, diligent, and patient. The leader also had to be careful and decisive in his management of participants' behavior, forbidding unreasonable requests and preventing personal opinions, jealousies, and selfish feelings from intruding into the experiment. Once contact was established with a spirit, the leader needed to exercise his skill to discern the true identity of the interlocutor and unmask any impostors. He had to endeavor to "purify the morals of inferior spirits" and thwart the disruptions of "vulgar and riotous spirits" who often wreaked havoc on séances. ${ }^{51}$ This spirit-sifting was, in effect, a method of distinguishing admissible experimental evidence from errors and deceptions. Moral facts could speak for themselves only when extraneous noise and interference was silenced. ${ }^{52}$

\section{IS L AMIC APPROPRIATIONS}

Khalil Khan did not see his own turn to experimental spirit science as a move to legitimize preexisting commitments. He considered his scientific interest in spirit communication and his moral ideas to have developed in tandem. These moral ideas had something in them of the virtues of positive science as Khalil Khan had come to understand the latter through his education at the Dar al-Funun and in Paris. Like the facts of physics and mathematics, he thought of moral facts as universally valid and transcending the fruitless squabbling of theologians. These facts could only be grasped by a free-thinker dedicated to an ascetic, disciplined study of the empirical facts of the spirit world, not through theological speculation or blind imitation of religious authority. And although this study was ostensibly open to anyone with the right

${ }^{50}$ Ibid.: 253. This emphasis on hard work and discipline as requirements for progress was very much a feature of modernist thought at the time. See Schayegh 2009.

51 Saqafi and Bahrami 1936: 43-45.

52 On Allan Kardec's theory of inferior souls and the esprit faux savant, or poseur spirit, see Monroe 2008: 130-35. 
instruments, it required a virtuoso ability to manage experiments to sift admissible evidence from the wiles of mischievous spirits and the passions and jealousies of participants.

Before long, experimental spirit science attracted interest from outside the network of committed Spiritists. This may have been what Khalil Khan had hoped for when he began to popularize Spiritism in his essays and his society's meetings. But as séances propagated, adherence to the doctrine of reincarnation and spiritist teachings on the progression of souls became dispensable. Other authors wrote about hypnotism, telepathy, communication with spirits, and other "spiritual sciences" independently of Kardec's dogmas. For example, Heshmat-Allah Dowlat-Shahi (1904-1980) founded a religious movement he dubbed "The New Universal Unity" (vahdat-e novin-e jahani) and incorporated hypnotism, telepathy, and communication with souls into his group's spiritual practice, without accepting spiritist reincarnation. ${ }^{53}$ Mohammad 'Anqa (1887-1962), a bureaucrat and Sufi whose son Sadeq would establish the universalist Oveysi Shah-Maqsudi order, also dabbled in hypnotism and communicated with spirits following years of association with Khalil Khan's spiritist society. ${ }^{54}$ And in what was perhaps the most mainstream of Sufi appropriations of hypnotism, Soltan Hoseyn Tabandeh Gonabadi Reza Ali-Shah (1914-1992), the future pole (qotb) of the Ne'matollahi Soltan Ali-Shahi order, wrote an essay in 1939 on "magnetic sleep" (hypnotism) to be appended to his great grandfather's treatise on sleep and dreaming. ${ }^{55}$ In it he suggested that Western research into hypnotism may have been informed by the works of Indian ascetics, Muslim mystics, and "spiritual occult science." natural sleep, Tabandeh wrote, the "artificial sleep" induced by hypnotism proved the immateriality of the soul (tajarrod-e ruh) and the existence of a realm beyond the material.

The Shi'i 'ulama soon took notice, too, although their exposure to Spiritism and psychical research largely occurred independently of the mediation of Khalil Khan and his circle. An influential alternative source was an Arabic-language encyclopedia published in the 1910s by the Egyptian scholar Muhammad Farid Wajdi. Wajdi spent a considerable part of his career attacking materialism and asserting the truth of Islamic doctrine. ${ }^{57}$ In the fourth volume of his encyclopedia, a full thirty-six pages of the section on ruh (the spirit) was devoted to sensory evidence of the existence of spirits as reported by European scientists, among whom he included the chemist and physicist William Crookes, astronomer Camille Flammarion, neurologist

53 Modarresi Chahardehi 2010: 271-73.

54 van den Bos 2002: 80-81; Modarresi Chahardehi 2010: 315.

${ }^{55}$ Bidokhti Gonabadi 2006.

56 Tabandeh Gonabadi 2006: 98.

${ }^{57}$ On Wajdi, see Jansen 2012. On Wajdi's attacks on materialism and his debts to Spiritualism and psychical research, see Elshakry 2013: 281-83. 
Jules Bernard Luys, electrical engineer Cromwell Varley, and naturalist Alfred Russell Wallace. These pages would prove extremely valuable to Shi' $\mathrm{i}$ 'ulama in their own polemics from the 1940s onward. ${ }^{58}$

Ayatollah Ruhollah Khomeini was an early adopter of Wajdi's arguments in his well-known 1944 treatise, Kashf-e Asrar (Unveiling of secrets). The book was a ferocious counterattack against anticlerical intellectuals who had accused the clergy of disseminating superstitious doctrines among a gullible populace. One of these was belief in the power of the deceased imams to intercede with God to forgive petitioners' sins and cure their diseases. Ahmad Kasravi had asked, for example, if there was any belief more misguided than considering the helpless dead to be God's colleagues. ${ }^{59}$ For Khomeini, the dispute turned in part on whether spirits survived their mortal bodies and could continue to be efficacious in the world of the living. The permanence of the spirit beyond death, he wrote, was attested by philosophical reason. ${ }^{60}$ In support of his argument, he cited evidence from the Qur'an as well as enumerating the views of a range of philosophers-Thales of Miletus, Anaximenes, Empedocles, Pythagoras, Socrates, Plato, Aristotle, Avicenna, Suhrawardi, Mulla Sadra, and Descartes - finally arriving at modern European and American Spiritualists, mesmerists, hypnotists, and psychical researchers. Of the latter, he wrote: "Magnetism or magnetic sleep [nowm-e meqnatisi] has strongly shaken the world and the materialists are breathing their last breaths. In the near future, science will completely lift the veil from this topic and will make manifest the world of spirits and their eternal life and their strange phenomena such as the insensitivity [to pain] of those in magnetic sleep, and their reports of the unseen [gheyb-gu' $i]$ and hundreds of other astonishing secrets. [This science] will forever remove the foundations of materialism from the world." 61

While discussing hypnotism and séances with disembodied spirits, Khomeini made several references to Wajdi's encyclopedia. As an example of astonishing spiritual manifestations, he translated Wajdi's account of an incident that allegedly involved Jules Luys - whom, it might be recalled, Khalil Khan had cited as his inspiration for studying experimental spirit science:

\footnotetext{
58 Wajdi was not a faithful reporter of European scientists' views on spirit phenomena. For one thing, he conflated Spiritists with psychical researchers and had them all attest unequivocally to the truth of the "spirit hypothesis" when many had openly opposed this hypothesis and others had been agnostic. For my purposes, that Wajdi was not a reliable transmitter is irrelevant. His Shi'i readers treated him as if he was, and I discuss their understanding of European Spiritism (which should be understood as Spiritism and psychical research together) as filtered through Wajdi, rather than as presented by European sources.

59 Kasravi 2011.

60 Khomeini n.d.: 30-31.

61 Ibid.: 53 .
} 
One of the things that [Wajdi] cites in the encyclopedia is that Luys, who is a famous hypnotist [khab-konandeh], put a woman to sleep in the presence of a group and told her to go home and see what people were doing there. The sleeping woman said "I went there. Two people are doing the house chores." Luys told her to put her hand on the body of one of them. At this point the sleeping woman laughed and said "I put my hand on one of them as you ordered me to do, and they were very scared." Luys asked those present if anyone knew the woman's house. One said that they did. He asked them to go to her house and see if the story was correct or not. They went and saw that the residents of the house were in fear and panic. They asked the reason and were told that they had seen a figure [heykal] in the kitchen that moved and put a hand on someone there. ${ }^{62}$

Like Wajdi, Khomeini saw the significance of reports like this to lie in their verification by sense-data of what had already been confirmed by revelation and philosophical reason. Moreover, they were attested by "recurring scientific testimonies" (tavator-e naql-ha-ye 'elmi), reports so numerous that they left no space for doubt about error or conspiracy to fabricate. ${ }^{63}$

Unveiling of Secrets was one of Khomeini's very few forays into public intellectual engagement. Over a decade later, a younger generation of mediasavvy scholars in Qom founded Dars-hayi az Maktab-e Eslam (Lessons from the school of Islam), a monthly magazine that addressed the urban educated classes with a clear and unapologetic Shi'i Islamic revivalist voice and quickly established itself as an articulate public-outreach arm for the Qom hawza. The magazine set a new standard for Islamic discourse that was shorn of complicated scholarly prose, openly engaged contemporary national and global events (while attempting to steer clear of direct criticism of the regime), embraced scientific discoveries and technological progress, and did all of this with philosophical and theological sophistication. Khomeini was to develop a theory of Islamic governance and go on to lead the 1979 revolution, but the editors and contributors to Lessons from the School of Islam did much of the groundwork in shifting educated public opinion toward an activist, progressive, universalist, scientifically minded Islam.

62 Ibid.: 55. Wajdi's account appears in Wajdi 1913: 369-70.

${ }^{63}$ In the Islamic legal tradition, recurring testimonies are a category of reports about the Prophet Muhammad that have been narrated through so many different chains of transmission that they carry hujjiya or probative force (Gleave 2002). In the philosophical and theological tradition, the mutawatirat are those sensibly observable things that we have heard about through recurring testimony, so much so that certainty is impressed on our minds and we consider it impossible that they have all been the products of error, or of collusion on a lie. For a discussion of the concept in the thought of Al-Ghazali, see Weiss (1985). In its outlines, the relevance of recurring scientific testimony to the persuasiveness of psychical research is hardly unique to the Egyptian and Iranian contexts. European psychical researchers and Spiritists made similar arguments. See for example Monroe's account of Xavier Dariex, a doctor who directed the journal Annales des sciences psychique from 1891 and who believed that "the eminence of the "men of science" who had observed the séances of gifted mediums like Eusapia Paladino was "more than enough proof for any rational observer" (Monroe 2008: 209). 
In the late 1960s, the magazine had the occasion to flex its intellectual muscles against Iranian Spiritism. The latter had found a new and energetic advocate in Abol-Qasem Farzaneh, an essayist for the popular modernist weekly Ettela'at-e Haftegi. Farzaneh wrote stories about communication with the spirits of the dead, explicated the doctrine of reincarnation and the progression of souls that was once promulgated by Khalil Khan and his circle, and instructed his readers on simple methods for holding séances. Soon thereafter, "summoning spirits" (ehzar-e arvah) became a common household pastime. Critics called it an "epidemic" (epidemi) and a "fad" (mod). In January 1969, Naser Makarem Shirazi, a founder and regular columnist for Lessons from the School of Islam tackled the subject with a series of critical essays published over the span of a year. ${ }^{64} \mathrm{He}$ began by arguing at length against the doctrine of reincarnation, and later examined the séance as a site of alleged communication with the spirits of the dead. Makarem did not reject the possibility of contact with spirits outright. Rather, he investigated the specific circumstances in which Iranian Spiritists operated to show that they could not withstand scrutiny:

No one can deny the existence of the soul ... because the philosophical, sensory, and empirical reasons that have been provided for proving the existence of the soul are too numerous to be ignored. Moreover, given the ample evidence that exists, one cannot deny the possibility of contact with souls through appropriate scientific means for those experienced individuals who have truly worked and struggled toward this end.... But no logic or reason can accept a condition in which such an important matter is belittled to the point that anyone can construct a turning table for fun and entertainment ... one night to summon the soul of Avicenna and another night to bother al-Razi, and a third night to menace Einstein ... and to make anything and everything into a topic of discussion - from the due date of Mrs. X to the truth or falsity of religions and sects and philosophical schools.... ${ }^{65}$

Even so, the monthly invited readers to submit evidence from "sense-data and observation" (hess va moshahedeh) to "practically demonstrate the possibility of contact [with spirits]," saying it would be open to publishing the results, no matter what, to complement the discussion. ${ }^{66}$

Rather than waiting for such evidence to be presented by third parties, Makarem decided to conduct his own experiment in the city of Sabzevar to evaluate the claims of the Iranian Spiritists. ${ }^{67}$ In the span of three short essays, he provides a wonderfully detailed ethnographic description of a séance, along with a more general discussion of the technology of the table, the procedures for establishing contact with spirits and interpreting their

64 Makarem later participated in the 1979 revolution and became a prominent marja'-e taqlid, or model of emulation, in the 1990s. He remains enormously influential at the time of this writing.

65 Makarem Shirazi 1969a: 70.

66 Makarem Shirazi 1969c: 17.

67 Makarem Shirazi 1969b: 7. 
messages, the beliefs and opinions of different practitioners and participants about the process, and the social and historical context of the recent "fad." 68

The particular séance that Makarem attended was led by a young man who also doubled as a medium. A private meeting of only a few men was convened at around 11 p.m. The young man used a small but relatively heavy squareshaped table for contact. Seated on a chair and with both palms on the table's surface, he recited a hamd va sureh ${ }^{69}$ and asked the participants to do the same, then stared at the table and asked the spirits in a quiet but deliberate tone to establish contact. After a few moments, the wooden planks in the table made a slight noise. The young medium again entreated the spirits to enter into communication with him: "Please I ask you to establish stronger contact." All of a sudden, the front side of the table rose about ten or twenty centimeters from the ground. Makarem notes that one of the participants thought the table had risen as a result of the medium's manual pressure, "and it was indeed something to suspect!" but the idea was that the movement was caused by the spirits, not by manual force, and Makarem decided to follow along.

Having established contact, the medium asked the spirit to introduce itself. He recited the alphabet from the beginning and whenever the table rose, two participants would jot down the letter at which the movement had taken place. The table would then fall back to the ground and the medium would start the alphabet from the beginning. "Soon it became apparent," Makarem writes, "that the spirit... was 'B-O-R-U-J-E-R-D-I,' that is, the late Ayatollah [Hoseyn] Borujerdi," who, it so happened, had been Makarem's teacher and his magazine's most powerful advocate from its founding until his death. ${ }^{70}$

Borujerdi had a message in Arabic for the gathering, which the men recorded as follows: "qal allah ta 'ala qulu la ilah illa 'llah tuflihu" (God Almighty said: Say there is no god but God, [so that] you will succeed). But when the participants carefully examined the disjointed letters that they had connected to form the sentence, they realized first that there were several discrepancies (an extra letter here, a missing letter there). Second, there were spelling errors that were "improbable to have been committed by the late Ayatollah Borujerdi," since he had been a master of Arabic literature. But if these were negligible issues, there was a more important matter: the famous saying the spirit had quoted came from the Prophet Muhammad, not God: "This error by the spirit of Ayatollah Borujerdi could not be ignored! And it gave us the right to doubt the veracity of the contact."

68 Makarem Shirazi 1969b; 1969c; 1970b.

69 Hamd va sureh consists of the first chapter of the Qur'an (Al-Fatiha) followed by another short chapter, usually Al-Ikhlas (surah 112). The combination is often recited silently as a prayer for the dead.

70 Ayatollah Hoseyn Tabataba'i Borujerdi (1875-1961) was director of the Qom hawza for seventeen years and the only marja'-e taqlid of the Shi'a world for the last fifteen years of his life (Algar 1989). 
Makarem was asked if he wanted to put any questions to the spirit of Ayatollah Borujerdi. He said he wanted to know what would become of the hawza in Qom, since this was an issue that had worried many hawza scholars since the death of their doyen. The spirit gave a "general response, which we all knew." Unsatisfied, Makarem asked the medium to request that the spirit provide a "sign" pertaining to the relationship between Ayatollah Borujerdi and Makarem and others among the former's students who lived in Qom during his lifetime. This needed to be a private sign, something of which others had not been aware. Alternatively, Makarem suggested that he could ask the spirit a question and request that he respond in Arabic. Or he could think of something and ask the spirit to read his mind, since the medium and others had claimed that spirits could read minds. At least one of these items would be required to convince Makarem that they had in fact been communicating with the spirit of his teacher.

At this point, contact broke off for "unknown reasons," and the spirit left the gathering. The medium attempted to re-establish communication, but other spirits made themselves available in Ayatollah Borujerdi's stead. Each offered some rather uninteresting statements. But Makarem wanted to speak only to Borujerdi and insisted on receiving his private sign. "The point in all of this was," he writes, "that we should not accept something without examination. Reason would not allow us to yield with our eyes and ears closed, and God would not be satisfied either." Such a sign was not forthcoming. One spirit launched into a tirade against Makarem for his skepticism. Another said that he would make himself manifest, but then appeared only to the medium. Makarem concludes that "the issue of the round and long tables" is more of a game than reality, and the messages that are communicated are the products of the medium's unconscious working through the nerves in his hands, rather than the intervention of any spirits. ${ }^{71}$

Although Makarem thus publicly discredited a single séance, he did not generalize his finding to all séances. Not only did he accept the testimony of European scientists about their own communications with spirits, he also left open the possibility that he could be persuaded of such contacts in Iran. This opening, however, was presented as a challenge that proved his victory over the Iranian Spiritists by default. "In two issues of the magazine printed in tens of thousands of copies," he wrote: "we invited those who claim to establish contact with spirits ... to do so in practice at a gathering of people of virtue and knowledge [majma 'i az ahl-e fazl va danesh]. We promised to print what we observe exactly in the magazine.... We once again renew this invitation and we add that the magazine will pay the expenses of such a person's travel to Qom and five days' stay at one of Qom's first-rate hotels on the condition

71 Makarem Shirazi 1969d. 
that this person obtain convincing signs from the spirit that are acceptable to the knowledgeable [ahl-e ettela ]."72

In sum, so far as Makarem was concerned, trustworthy evidence of communication with spirits was of two kinds: Either it had to come by way of recurring testimony of respected "people of virtue and knowledge" such as European scientists and Muslim jurists, or it had to be the product of sensory perception verified by a rational, skeptical mind. With the first kind of evidence, Makarem established an equivalence between modern scientists and hawza scholars. With the second, he acknowledged that the spirit could be the object of sensory perception while adding the qualifier that the kind of evidence that could point to the existence of spirits could also point to trickery or the movements of the unconscious mind. Only a select few had the ability to discern the difference and they did so under strictly controlled experimental conditions.

Wajdi had provided the details of the strict experiments under which European scientists had ostensibly observed genuine spiritual phenomena. Makarem cited Wajdi's claim that these scientists would "tightly bind the medium to a chair, and sometimes even confine him or her to an iron cage, lock the door of the room in which the experiment was taking place, and attach electric wires to the medium's hands to detect any movement, no matter how slight or quick ... in order to ascertain that these [extraordinary] actions were related to spirits, not the person of the medium."73 Makarem concluded that "one can accept that Spiritism ... has passed the threshold of theoretical interest to become an empirical science based on sense-data," but this scientific endeavor had been misappropriated by charlatans and the naïve who thought that they could "establish contact with spirits great and small without any scientific information and merely using a turning table or a cup on a page full of letters." 74

In his year-long polemic against Iranian Spiritism, Makarem did more than refute a set of doctrinal statements and empirical claims about spirits. He also modeled what he thought theological reasoning in a mass-circulating magazine should look like. The norms to which Makarem self-consciously adhered had to do both with the conventions of public reasoning that his readers took for granted and a set of virtues that he and his colleagues at the magazine wanted to promote. Although Makarem's polemics against reincarnation merit attention in their own right, I will focus my remarks only on his empirical arguments, because it is here that we can find the enactment of certain virtues associated with professional scientific practice.

\footnotetext{
72 Ibid.: 9 .

73 Makarem Shirazi 1970a.

74 Makarem Shirazi 1970b: 60.
} 
Like Khalil Khan, Makarem believed that scientific practice required dedication and hard work. The former would have agreed with Makarem's assessment that contact with spirits was possible only "for those experienced individuals who have truly worked and struggled toward this end." ${ }^{, 75}$ For Makarem this dedicated struggle involved, as I have indicated, an unflinching attention to controlling the setting of the experiment to weed out any possibility of error or deception. Khalil Khan, too, believed this was necessary, but since he was convinced that it was indeed spirits who were responsible for the turning of tables and the automatic writing of mediums at his séances, he seemed to be less concerned with human trickery and observational error than with the disruptions of inferior and poseur spirits.

If Makarem's European Spiritists confined mediums to iron cages and attached galvanometers to their limbs to detect the slightest movements, Makarem himself would scrupulously note every detail of the experiment he observed: what time it occurred, features of the table used for contact, the medium's behavior, details of the messages that were conveyed, and so forth. It was through this scrupulous attention that he was able to detect signs of conscious or unconscious human intervention that obviated the claim that the experimental evidence the medium produced had an otherworldly provenance: Did the table rise due to the medium's manual pressure? Would Ayatollah Borujerdi's spirit have committed Arabic spelling errors?

This brings us to another virtue Makarem emphasized as proper to scientific discovery: skepticism. Given the range of possible causes for alleged spiritual phenomena, he believed that a scientific approach to them required that the experimenter maintain a skeptical posture in order to rule out the alternatives. The scientific testimonies he read in Wajdi's encyclopedia were all the more compelling because the European scientists cited there had embarked on their studies with a spirit of suspicion and even of contempt. Khalil Khan, in his attention to the control of experimental conditions, would have recognized the importance of skepticism as well. But for Khalil Khan, as for the French Spiritists and psychical researchers who inspired him, the skepticism of the majority of the representatives of organized science amounted to a dogmatism that undermined the spirit of scientific exploration that depended on openmindedness and curiosity. ${ }^{76}$ Rather than emphasizing skepticism, he called for suspending judgment until scientific confirmation could be secured, even though by suspension of judgment he really meant suspending the urge to deny. ${ }^{77}$ We have seen that Makarem, too, demonstrated scientific

${ }^{75}$ Makarem Shirazi 1969a: 70.

76 The conflict between camps that emphasize scientific skepticism against credulity and those that stress scientific open-mindedness against establishment dogmatism has been a recurring feature in the development of modern fringe sciences from mesmerism through psychical research, parapsychology, and ufology. See Brower 2010; Denzler 2001; and Monroe 2008.

77 See his book of advice (Saqafi 1907), especially numbers 33, 39, and 50. 
open-mindedness, both by accepting the testimony of European scientists and by claiming that he was willing to entertain any evidence provided by the Iranian Spiritists so long as it met his conditions. The balance of skepticism and open-mindedness, however, produced very different results in the two men's work.

Dedication, scrupulousness, and skepticism were the ingredients that went into the making of "people of virtue and knowledge"; that is, those whom Makarem considered trustworthy sources of scientific testimony. In the course of his polemical engagement with Spiritism, he performatively modeled these virtues while hinting that "virtue and knowledge" might not be restricted to jurists and theologians in Qom, but characterize European scientists as well. In the context of a mass-circulating Islamic magazine of the 1960s, this was a masterful move. In one fell swoop, he showed his audience that Muslim theologians were men of reason and science rather than superstition and backwardness, he undercut the Iranian Spiritists' claims to association with European science, and he laid out for his pious readership what a synthesis of Islamic rationality and a commitment to science and progress should look like. His insistence that "Reason would not allow us to yield with our eyes and ears closed" his magazine (and one in which he participated repeatedly himself): to demonstrate the firm rational grounding of Shi' $i$ doctrine. Of course, this also meant that Makarem was making theological reason-'aql-commensurable with scientific rationality.

While Makarem's theologico-scientific exploration was characterized by certain scientific virtues, its object was ultimately moral. In this, again, we see an affinity between Makarem's project and that of Khalil Khan and his Spiritist colleagues, and again there are important divergences. Makarem worried about a condition of moral and epistemological anarchy in which anyone with a talent for the "game" of table-turning could not only make claims about religion, philosophy, and the order of the universe, but attract a following as well. ${ }^{79}$ His concern was particularly acute in an era of uncertainty about the future of Shi'i religious leadership and the role of the hawza after Ayatollah Borujerdi. It was only fitting that his one experience with a séance should turn into a showdown over who had the right to inherit the authority of, and indeed speak for, the great marja': his qualified student, or a young provincial medium.

If Khalil Khan had discovered positive moral facts through his séances with the spirits of the dead, Makarem undercut such claims to moral truth, which he saw as anarchic, by discrediting the séance. For Makarem, moral truth was not to be found in a turning table or the automatic writing of a

78 Makarem Shirazi 1969d.
79 Makarem Shirazi 1970c. 
medium. Even though he did not explicitly state this, there is little doubt that he saw the "people of virtue and knowledge" not only as good empirical observers but as trustworthy exponents of virtue as well. Regarding the latter, he would have restricted the people of virtue and knowledge to the jurists and theologians in Qom. None of the European scientists Wajdi had cited said anything about morality beyond affirming the truth of immaterial existence and disparaging materialism. For Makarem, this was as it should have been.

How might the virtues proper to scientific experiment be related to those virtues discovered, sustained, or defended through such experimentation? For Khalil Khan and his Spiritist colleagues, the two were inseparable. Scientific virtues like free-thinking, discipline, and patient struggle were valuable in themselves, but they were also indispensable as enabling virtues, as those dispositions through which positive, infallible moral facts could be discovered, appreciated, and secured. Without the first set of virtues, the séance participant risked falling prey to his or her own passions or superstitions, or to the deceptions of inferior spirits.

For Makarem, scientific virtues like skepticism, diligence, openmindedness, and scrupulousness belonged more squarely with the scholarly elite. The task of investigating the séance was not one that he would recommend for everyone. "I confess," Makarem wrote, "that participation in these meetings might not be appropriate for ordinary people. But for those who have a duty to conduct research or provide guidance to others, it sometimes gains an aspect of necessity." 80 Ordinary people did not need to equip themselves with the tools of scholarly investigation as long as scholars like Makarem were around to guide them. In other words, the point of this series of public engagements was not so much to inculcate the virtues of scientific or theological scholarship as it was to persuade his readership that their guides had the scholarly competence and virtuous sensibilities that qualified them for their job.

\section{CONCLUSION}

The power of the modern sciences in Iran was not built in spite of deep-seated moral and religious commitments, but partly because of them. The Islamic embrace of scientific empiricism has been increasingly well-documented. I hope to have contributed to this literature by showing how activist Shi' $i$ scholars appropriated scientific knowledge and method to defend Islamic doctrine and the moral health of the Muslim community, but also to construct a rationalist position from which to attack a congeries of heterodox positions, from materialism through deism to reincarnation. Less appreciated has been the extent to which the promotion of the modern sciences was entangled with religious

80 Makarem Shirazi 1969b. 
projects outside the fold of Islam. Spiritism is a particularly important case, but by no means the only one. Future research should account for the many ways in which Spiritism, its Anglo-American twin Spiritualism, and psychical research shaped the religious and intellectual milieus in the Muslim world in the first half of the twentieth century, as well as their continued reverberations into the present.

The gift of modern science to Iranian religious thinking has not been purely epistemological. As I have shown here, it has been fundamentally moral as well. The virtues of professional scientific practice imagined by moral reformers - values like open-mindedness, skepticism, diligence, and scrupulousness - were sometimes treated as fully consistent with an existing tradition, as by Shi'i scholars like Makarem, and at other times as effecting a break with the past, as by Khalil Khan and his Spiritist circle. I have shown that it was both: the scientific virtues were new to the extent that their formulations depended on representations of modern European scientific activity, but they were absorbed into a longstanding tradition of moral refinement and virtuous self-fashioning and therefore rendered continuous with a cherished past.

These observations can help us reassess some scholarly understandings of the religious appropriation of scientific empiricism that are considered primarily in terms of epistemology. Many such appropriations have been characterized as rhetorical and defensive. By calling these appeals "rhetorical," what is meant is that they are scientistic but not scientific, that they use the vocabulary of science without embodying its spirit, or at least without convincing mainstream scientists that they have done so. They are the outcome of strategies for legitimating existing doctrines rather than of commitment to scientific methods. $^{81}$ By calling them "defensive," what is meant is that religious appeals to science boil down to rearguard attempts to defend the relevance of traditional knowledge and its associated moral order against external attack. $^{82}$ To attend to the moral values of scientific practice is to shift the ground of the inquiry, such that what matters is no longer merely the defense of entrenched positions, but also the modalities by which people aspire toward virtuous futures. ${ }^{83}$ Such a framework requires us to attend to the possibility that the religious appeal to science may help constitute a mode of serious inquiry, and one that is, moreover, not so discontinuous with the religious past as we might imagine.

\footnotetext{
81 Olav Hammer (2001) makes a systematic case for this position in his study of the "epistemological strategies" of the followers of modern esotericism.

82 See Ahmad Dallal's reflections on this point (2010: 173). Dallal argues that modern Islamic appropriations of science are based in ignorance of the historical relationship between religious and scientific modes of knowledge in Islamic civilization. Moreover, some of these appropriations are reflective of "insecurity and a need to vindicate religion in the age of science."

${ }^{83}$ On this point, see also Telliel 2015.
} 


\section{REFERENCES}

Agrama, Hussein Ali. 2010. Ethics, Tradition, Authority: Toward an Anthropology of the Fatwa. American Ethnologist 37, 1: 2-18.

Algar, Hamid. 1989. Borūjerd̄̄, Hosayn Tabātabā'̄i. Encyclopedia Iranica, Online Edition. At http://www.iranica.com/articles/borujerdi-ayatollah-hajj-aqa-hosayntabatabai-1292-1380-1875-1961 (accessed 11 Dec. 2015).

Arjomand, Kamran. 1997. The Emergence of Scientific Modernity in Iran: Controversies Surrounding Astrology and Modern Astronomy in the Mid-Nineteenth Century. Iranian Studies 30, 1-2: 5-24.

Asad, Talal. 1986. The Idea of an Anthropology of Islam. Occasional Paper Series. Washington, D.C.: Georgetown University Center for Contemporary Arab Studies.

Asad, Talal. 1993. Genealogies of Religion: Discipline and Reasons of Power in Christianity and Islam. Baltimore: Johns Hopkins University Press.

Asad, Talal. 2015. Thinking about Tradition, Religion, and Politics in Egypt Today. Critical Inquiry. At http://criticalinquiry.uchicago.edu/thinking_about tradition_religion_ and politics in egypt today/ (accessed 11 Dec. 2015).

Bayat, Mangol. 2009. Freemasonry and the Constitutional Revolution in Iran: 19051911. In Andreas Önnerfors and Dorothe Sommer, eds., Freemasonry and Fraternalism in the Middle East. Sheffield: University of Sheffield, 109-50.

Bidokhti Gonabadi, Soltan Mohammad. 2006. Tanbih al-na'emin, beh payvast-e khab-e meghnatisi. Tehran: Haqiqat.

Bogdan, Henrik and Gordan Djurdjevic, eds. 2013. Occultism in a Global Perspective. Durham: Acumen.

Boroujerdi, Mehrzad. 2006. "The West" in the Eyes of the Iranian Intellectuals of the Interwar Years (1919-1939). Comparative Studies of South Asia, Africa, and the Middle East 26, 3: 391-401.

Brower, M. Brady. 2010. Unruly Spirits: The Science of Psychic Phenomena in Modern France. Urbana: University of Illinois Press.

Calverley, Edwin E. 2012. Nafs. In P. Bearman et al., eds., Encyclopedia of Islam. $2 \mathrm{~d}$ ed. Brill Online. At http://referenceworks.brillonline.com/entries/encyclopaedia-ofislam-2/nafs-COM_0833 (accessed 11 Dec. 2015).

Cecire, Natalia. 2015. Experimentalism by Contact. Diacritics 43, 1: 6-35.

Chehabi, Houchang E. 1990. Iranian Politics and Religious Modernism: The Liberation Movement of Iran under the Shah and Khomeini. Ithaca: Cornell University Press.

Dallal, Ahmad S. 2010. Islam, Science, and the Challenge of History. New Haven: Yale University Press.

Daston, Lorraine. 1995. The Moral Economy of Science. Osiris, 2d series, vol. 10, "Constructing Knowledge in the History of Science," 2-24.

Daston, Lorraine and Peter Galison. 1992. The Image of Objectivity. Representations 40 (special issue, "Seeing Science"): 81-128.

Deeb, Lara. 2006. An Enchanted Modern: Gender and Public Piety in Shi 'i Lebanon. Princeton: Princeton University Press.

Denzler, Brenda. 2001. The Lure of the Edge: Scientific Passions, Religious Beliefs, and the Pursuit of UFOs. Berkeley: University of California Press.

Elshakry, Marwa. 2009. The Exegesis of Science in Twentieth-Century Arabic Interpretations of the Qur'an. In Jitse van der Meer, ed., Nature and Scripture. Leiden: Brill, 491-524.

Elshakry, Marwa. 2013. Reading Darwin in Arabic, 1860-1950. Chicago: University of Chicago Press. 
Fuchs, Simon Wolfgang. 2014. Failing Transnationally: Local Intersections of Science, Medicine, and Sectarianism in Modernist Shi'i Writings. Modern Asian Studies 48, special issue 2: 433-67.

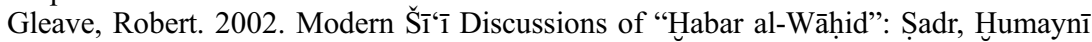
and Hū'̄i. Oriente Moderno, new series 21, 82, 1 ("Hadith in Modern Islam"): 179-94.

Green, Nile. 2015. The Global Occult: An Introduction. History of Religions 54, 4: 383-93.

Hadi, Abdollah. 1972. Khatereh-i az ehzar-e arvah. Khaterat-e Vahid 8: 42-46.

Hammer, Olav. 2001. Claiming Knowledge: Strategies of Epistemology from Theosophy to the New Age. Leiden: Brill.

Hess, David J. 1991. Spirits and Scientists: Ideology, Spiritism, and Brazilian Culture. University Park: Pennsylvania State University Press.

Hirschkind, Charles. 2006. The Ethical Soundscape: Cassette Sermons and Islamic Counterpublics. New York: Columbia University Press.

Hoskins, Janet A. 2015. The Divine Eye and the Diaspora: Vietnamese Syncretism becomes Transpacific Caodaism. Honolulu: University of Hawai'i Press.

Jansen, J.J.G. 2012. Muhammad Farid Wadjdi. In P. Bearman et al., eds., Encyclopedia of Islam, 2d ed. Brill Online. At http://referenceworks.brillonline.com/entries/ encyclopaedia-of-islam-2/muhammad-farid-wadjdi-SIM_5395 (accessed 11 Dec. 2015).

Karabela, Mehmet Kadri. 2010. The Development of Dialectic and Argumentation Theory in Post-Classical Islamic Intellectual History. PhD diss., Institute of Islamic Studies, McGill University.

Karimi-Hakkak, Ahmad. 1995. From Translation to Appropriation: Poetic CrossBreeding in Early Twentieth-Century Iran. Comparative Literature 47, 1: 53-78.

Kashani-Sabet, Firoozeh. 2000. Hallmarks of Humanism: Hygiene and Love of Homeland in Qajar Iran. American Historical Review 105, 4: 1171-203.

Kasravi, Ahmad. 2011. Shi 'i-gari. Los Angeles: Ketab Corp.

Khomeini, Ruhollah. n.d. Kashf-e Asrar. Tehran: S.n.

Kia, Mana. 2014. Adab as Ethics of Literary Form and Social Conduct: Reading the Gulistān in Late Mughal India. In Alireza Korangy and Daniel J. Sheffield, eds., No Tapping around Philology: A Festschrift in Honor of Wheeler McIntosh Thackston Jr. 's $70^{\text {th }}$ Birthday. Wiesbaden: Harrassowitz Verlag, 281-308.

Kia, Mana. 2015a. Moral Refinement and Manhood in Persian. In Margrit Pernau, et al., eds., Civilizing Emotions: Concepts in Asia and Europe, 1870-1920. Oxford: Oxford University Press, 146-65.

Kia, Mana. 2015b. Defining a Modern Persianate Self: The Indian Friend as Ethical Interlocutor in the late 19th Century. Mss.

Klassen, Pamela E. 2011. Spirits of Protestantism: Medicine, Healing, and Liberal Christianity. Berkeley: University of California Press.

Koyagi, Mikiya. 2009. Modern Education in Iran during the Qajar and Pahlavi Periods. History Compass 7, 1: 107-18.

Lachapelle, Sofie. 2011. Investigating the Supernatural: From Spiritism and Occultism to Psychical Research and Metapsychics in France, 1853-1831. Baltimore: Johns Hopkins University Press.

Lotfalian, Mazyar. 2004. Keywords in Islamic Critiques of Technoscience: Iranian Postrevolutionary Interpretations. In Ramin Jahanbegloo, ed., Iran: Between Tradition and Modernity. Lanham, Md.: Lexington Books, 15-24.

MacIntyre, Alasdair. 2012. After Virtue: A Study in Moral Theory. 3d ed. Notre Dame: University of Notre Dame Press. 
Mahmood, Saba. 2005. Politics of Piety: The Islamic Revival and the Feminist Subject. Princeton: Princeton University Press.

Makarem Shirazi, Naser. 1969a. Ertebat ba arvah: sargarmi ya bimari-ye "miz-e gerd." Dars-hayi az Maktab-e Eslam 10, 7: 68-71.

Makarem Shirazi, Naser. 1969b. Dar jalaseh-ye ertebat ba arvah cheh didam. Dars-hayi az Maktab-e Eslam 10, 8: 7-10.

Makarem Shirazi, Naser. 1969c. Aya ertebat ba arvah emkan-pazir ast? Moshahedat-e man dar jalaseh-ye ertebat ba arvah. Dars-hayi az Maktab-e Eslam 10, 9: 17-19, 24.

Makarem Shirazi, Naser. 1969d. Aya ertebat ba arvah emkan darad? Amma 'aqideh-ye ma darbareh-ye ertebat ba arvah. Dars-hayi az Maktab-e Eslam 10, 11: 9-11.

Makarem Shirazi, Naser. 1970a. 'Elmi beh nam-e espiritism. Dars-hayi az Maktab-e Eslam 11, 1: 10-12.

Makarem Shirazi, Naser. 1970b. Ertebat ba arvah: Natijeh-ye nahayi-e bahs-e ertebat ba arvah. Dars-hayi az Maktab-e Eslam 11, 2: 58-60.

Makarem Shirazi, Naser. 1970c. Baz ham darbareh-ye tanasokh va 'owd-e arvah. Dars-hayi az Maktab-e Eslam 11, 10: 16, 67-72.

Masud, Muhammad Khalid. 2015. Adab al-Muftī. In Kate Fleet et al., eds., Encyclopedia of Islam, THREE. Brill Online. At http://referenceworks.brillonline.com/entries/ encyclopaedia-of-islam-3/adab-al-mufti-COM_26301 (accessed 11 Dec. 2015).

Mazhari, Mohammad. 1977. Anjoman-e ma'refat al-ruh-e tajrobati-ye iran. Vahid 210: 41-44.

Modarresi Chahardehi, Nur al-Din. 2008. Espiritism: 'Elm-e ertebat ba arvah. Tehran: Afarinesh.

Modarresi Chahardehi, Nur al-Din. 2010. Seyri dar tasavvof: Dar sharh-e hal-e mashayekh va aqtab. Tehran: Entesharat-e Eshraqi.

Monroe, John Warne. 2008. Laboratories of Faith: Mesmerism, Spiritism, and Occultism in Modern France. Ithaca: Cornell University Press.

Najmabadi, Afsaneh. 2014. Professing Selves: Transsexuality and Same-Sex Desire in Contemporary Iran. Durham: Duke University Press.

Palmié, Stephan. 2002. Wizards and Scientists: Explorations in Afro-Cuban Modernity and Tradition. Durham: Duke University Press.

Parent, André. 2002. Jules Bernard Luys (1828-1897). Journal of Neurology 249: 1480-81.

Parent, Martin and André Parent. 2011. Jules Bernard Luys in Charcot's Penumbra. In Julien Bogousslavsky, ed., Following Charcot: A Forgotten History of Neurology and Psychiatry. Basel, N.Y.: Karger, 125-36.

Ridgeon, Lloyd. 2006. Sufi Castigator: Ahmad Kasravi and the Iranian Mystical Tradition. London: Routledge.

Ringer, Monica. 2001. Education, Religion, and the Discourse of Cultural Reform in Qajar Iran. Costa Mesa, Calif.: Mazda Publishers.

Rudnyckyj, Daromir. 2010. Spiritual Economies: Islam, Globalization, and the Afterlife of Development. Ithaca: Cornell University Press.

Saqafi E'zaz, Hoseyn. 1972. Towzihat dar khosus-e khatereh-ye aqa-ye 'eyn hadi va mabhas-e ruh-shenasi va ertebat ba arvah. Khaterat-e Vahid 9, 10: 99-105.

Saqafi, Khalil. 1891-1892. Tarbiyat-nameh. Tehran.

Saqafi, Khalil. 1907. Kelid-e zendegi. Tehran: Matba'eh-ye Parsian.

Saqafi, Khalil. 1929. Haftad va yek maqaleh-ye ma'refat al-ruh. Tehran: Jame'eh-ye ma'aref-e iran.

Saqafi, Khalil. 1935. Sad va panjah maqaleh yadegar-e 'asr-e jadid. Tehran: Majles. Saqafi, Khalil. 1943. Maqalat-e gunagun: Maqalat-e tarikhi, siasi, adabi. Tehran: n.p. 
Saqafi, Khalil and Ali-Reza Bahrami. 1936. Kelid-e shenasa'i dar 'alam-e gheyr-e mar'i. Tehran: Majles.

Schaeffer, Simon. 1994. Self-Evidence. In James Chandler, Arnold I. Davidson, and Harry Harootunian, eds., Questions of Evidence: Proof, Practice, and Persuasion across the Disciplines. Chicago: University of Chicago Press, 56-91.

Schayegh, Cyrus. 2009. Who Is Knowledgeable Is Strong: Science, Class, and the Formation of Modern Iranian Society, 1900-1950. Berkeley: University of California Press.

Shapin, Steven. 1994. A Social History of Truth: Civility and Science in SeventeenthCentury England. Chicago: University of Chicago Press.

Shapin, Steven and Simon Schaeffer. 1989. Leviathan and the Air-Pump: Hobbes, Boyle, and the Experimental Life. Princeton: Princeton University Press.

Sharp, Lynn L. 2006. Secular Spirituality: Reincarnation and Spiritism in NineteenthCentury France. Lanham, Md.: Lexington Books.

Stanley, Matthew. 2007. Practical Mystic: Religion, Science, and A. S. Eddington. Chicago: University of Chicago Press.

Stolz, Daniel A. 2012. "By virtue of your knowledge": Scientific Materialism and the Fatwās of Rashīd Rị̣ā. Bulletin of SOAS 75, 2: 223-47.

Stolz, Daniel A. 2015. Positioning the Watch Hand: 'Ulama' and the Practice of Mechanical Timekeeping in Cairo, 1737-1874. International Journal of Middle East Studies 47, 3: 489-510.

Tabandeh Gonabadi, Soltan Hoseyn. 2006. Resaleh-ye khab-e meghnatisi. In Tanbih al-na'emin, beh payvast-e khab-e mighnatisi. Soltan Mohammad Bidokhti Gonabadi. Tehran: Haqiqat, 77-144.

Telliel, Yunus Dogan. 2015. Miraculous Evidence: Scientific Wonders and Religious Reasons. Mss.

Vahdat, Farzin. 2002. God and Juggernaut: Iran's Intellectual Encounter with Modernity. Syracuse: Syracuse University Press.

Vahid Sa'd, Mahmud. 1929. Tasfiyeh-ye akhlaq beh vasileh-ye tahammol-e masa'eb va anjam-e vaza'ef. In Khalil Saqafi, ed., Haftad va yek maqaleh-ye ma 'refat al-ruh. Tehran: Jame'eh-ye ma'aref-e iran, 248-78.

van den Bos, Matthijs. 2002. Mystic Regimes: Sufism and the State in Iran, from the Late Qajar Era to the Islamic Republic. Leiden: Brill.

van der Veer, Peter. 2001. Imperial Encounters: Religion and Modernity in India and Britain. Princeton: Princeton University Press.

Wajdi, Muhammad Farid. 1913. Da'irat ma'arif al-qarn al-rabi' 'ashar, al-'ishrin. Vol. 4. Cairo: Matba'a al-Qa'iz.

Warburg, Margit, Annika Hvithamar, and Morten Warmind, eds. 2005. Baha'i and Globalization. Aarhus: Aarhus University Press.

Weiss, Bernard. 1985. Knowledge of the Past: The Theory of 'Tawatur' According to Ghazali. Studia Islamica 61: 81-105.

Zarcone, Thierry. 2013. Occultism in an Islamic Context: The Case of Modern Turkey from the Nineteenth Century to the Present Time. In Henrik Bogdan and Gordan Djurdjevic, eds., Occultism in a Global Perspective. Durham: Acumen, 151-76. 
Abstract: This article examines some aspects of the reception of French Spiritism and psychical research in twentieth century Iran: its promotion by Iranian modernist intellectuals before the Second World War, and its appropriation by Shi' $i$ Muslim 'ulama in the 1940s and 1960s. Spiritism appealed to those intellectuals and scholars who sought to reconcile their commitments to science with their religious longings and dedication to moral reform. In comparing these encounters with spirit communication, I show that the adoption of putatively scientific claims in contexts that professional scientists usually disavow can be about much more than strategic appropriation and attempts to justify preexisting doctrines. They also allow us to understand science's power to mold the moral subjectivities of reformers through selective absorption into long-continuous traditions of virtue. 